\title{
Sosialisasi Penggunaan Lubang Biopori Dalam Rangka Mengurangi Banjir Di SMP Negeri 3 Cikarang Timur
}

\author{
Istianah Setyaningsih ${ }^{a, 1, *}$, Yenia Endriastuti ${ }^{b, 2}$ \\ ${ }^{a}$ Program Studi Ilmu Administrasi Publik, Fakultas Ilmu Administrasi, Institut STIAMI \\ b Program Studi Ilmu Administrasi Publik, Fakultas Ilmu Administrasi, Institut STIAMI \\ 1 istianah@stiami.ac.id *; ${ }^{2}$ yenia@ stiami.ac.id \\ * corresponding author
}

\section{ARTICLE INFO}

\section{Article history}

Received

Revised

Accepted

Keywords

Floods,

Biopori, Students

\begin{abstract}
Bekasi Regency, one of the districts affected when rainfall is high occurs according to data from BPS during 2016 the average rainfall reached 2,000.12 mm. Public Middle School 3 East Cikarang, one of the areas that has the potential for flooding, is caused by a lower land surface than the surrounding area. Biopori Infiltration Hole, is one of the techniques carried out for disaster mitigation and can be applied easily by everyone. The purpose of this study is to find out how much the benefits of biopori as a solution to minimize the potential for flooding applied in schools that are often affected by flooding. The benefit of this research is that students and the community know the benefits of biopori as a whole, not just as a flood prevention. The results obtained are overall knowledge about biopori, the benefits of applying biopori, designing a good biopori installation location, and also designing an effective biopori manufacture.
\end{abstract}

\section{A. PENDAHULUAN}

\section{Analisis Situasi}

Kabupaten Bekasi merupakan salah satu kabupaten di Indonesia yang terdampak apabila curah hujan tinggi terjadi. Menurut data BPS pada tahun 2017(BPS 2017), rata-rata curah hujan yang terjadi di Kabupaten Bekasi kurang lebih $2.000,12 \mathrm{~mm}$. Curah hujan yang tinggi berakibat volume air meningkat sedagkan daya serap tanah terhadp air berkuang, sehingga menyebabkan terjadinya banjir di beberapa titik di Kabupaten Bekasi. Pembukaan lahan, perataan dan pemadatan tanah untuk pembangunan permukiman maupun prasaran lainnya menjaid salha satu penyebab daya serapt tanah terhadpa air menurun. Selain itu berkurangnya sumber bahan organik dalam unsur tanah dan rusaknya lubang-lubang bekas penembusan galian faunah tanah juga menjadi penyebab menurunya daya serap tanah terhadap air. Banjri terjadi bukan hanya diarea permukiman saja, bahkan beberpaa sekolah di wilayah Cikarang Timur juga mengalami banjir salah satunya di SMP Negeri 3 Cikarang Timur. Kondisi tanah yang lebih rendah dari daerah sekitarnya menyebabkan SMP Negeri 3 Cikarang Timur sering mengalami banjir, selain kondisi tanah yang rendah banyaknya kegiatan pengecoran jalan dan pembangunan ruang tambanhan di sekitar sekolah juga menjadi penyebab banjir terjadi setiap kali musim penghujan tiba.

Upaya dalam mengatasi potensi terjadinya banjir dapat dilakukan dengan beberapa cara, seperti pemeliharaan saluran air serta pengelolaan pembuangan sampah. Salah satu upaya sederhana yang dapat dilakukan adalah dengan menggunakan teknologi sederhana tetapi memiliki dampak yang sangat besar bagi lingkungan yaitu Lubang Resapan Biopori (LRB). Lubang Resapan Biopori menjadi salah satu upaya yang mudah diterapkan di wilayah yang masih mengalami pembangunan, karena dana yang dibutuhkan sedikit serta efektif dalam proses penyerapan air dan dapat mengurangi jumlah sampak organik.

Lubang Resapan Biopori (LRB) ditemukan dan dikembangkan oleh seorang dosen Ilmu Tanah dan Sumber Daya Lahan Institut Pertanian Bogor, Jawa Barat pada tahun 2000 yang bernama Ir. Kamir R. Brata, MSc. Menurut Kamir, lubang resapan biopori yang baru dibuat serta telah diisi sampah bisa memasukan air sebanyak 1,5 liter hingga 16 liter per menit. Lubang resapan biopori (LRB) adalah lubang-lubang tanah yang terbentuk akibat aktivitas organisme di dalamnya, seperti cacing, perakaran tanah, rayap, dan fauna tanah lainnya. Dengan adanya aktivitas fauna tanah pada lubang resapan maka biopori akan terjaga kemampuannya dalam menyerap air dan akan terus terpelihara keberadaannya. 
Selain dapat meresapkan genangan air saat terjadi hujan dengan cepat, lubang resapan biopori (LRB) juga dapat menjaga ketersediaan cadangan air tanah dikala musim kemarau datang, serta juga dapat meminimalisir volume sampah organik yang berserakan dan mengolahnya menjadi kompos dengan cara memasukan media sampah-sampah organik, seperti daun, rumput, sampah rumah tangga, dan sampah lainnya ke dalam lubang biopori sebagai upaya untuk menjaga kesuburan tanah.

Gambar 1. Lubang Resapan Biopori

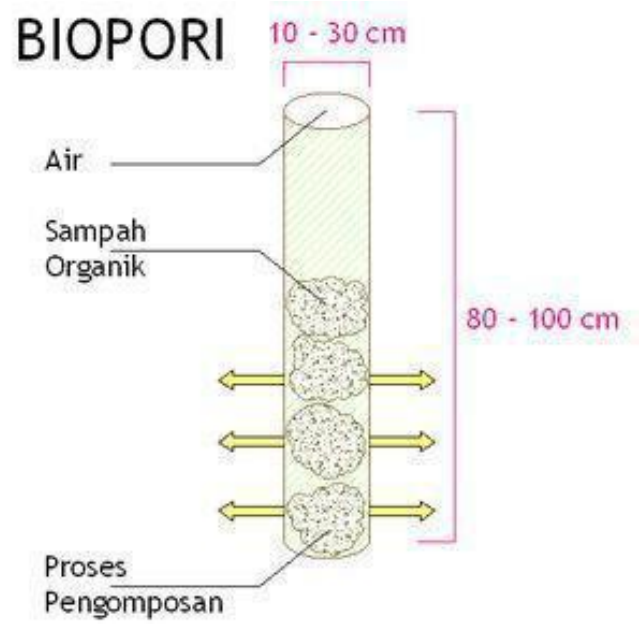

Lubang resapan biopori tidak memerlukan lahan yang luas. Untuk daerah dengan intensitas hujan tinggi dan laju peresapan air sekitar 3 liter per menit, setiap 100 meter persegi luas tanah, hanya akan membutuhkan 28 lubang. Oleh karena itu, teknologi ini bisa diaplikasikan di semua jenis kawasan, termasuk kawasan yang sangat kedap air dan jika biopori itu berada diantara pepohonan, tumbuhan tersebut akan tumbuh dengan subur.

\section{Perumusan Masalah}

Berdasarkan urian di atas dapat dirumuskan permasalahan sebagai berikut:

1. Bagaimana warga SMP Negeri 3 Cikarang Timur dapat mengetahui, merancang serta membuat Lubang Resapan Biopori.

2. Bagaimana warga SMP Negeri 3 Cikarang Timur dapat berpartisipasi dalam mengendalikan banjir melalui pembuatan Lubang Resapan Biopori.

\section{Tujuan}

Kegiatan ini memiliki tujuan, antara lain :

1. Memberikan pengetahuan dan wawasan kepada warga SMP Negeri 3 Cikarang Timur tentang Lubang Resapan Biopori .

2. Menambah ketrampilan kepada warga SMP Negeri 3 Cikarang Timur dalam pembuatan Lubang Resapan Biopori

\section{Manfaat}

1. Memaksimalkan air yang meresap kedalam tanah sehingga dapat menambah cadangan air tanah

2. Mengurangi resiko banjir yang terjadi di sekitar wilayah SMP negeri 3 Cikarang Timur

\section{B. GAMBARAN UMUM MASYARAKAT SASARAN}

SMP Negeri 3 Cikarang Timur adalah salah satu sekolah yang terletak di Kota Cikarang Kabupaten Bekasi, tepatnya berada di Kampung Rawa Gebang RT.005/RW.003 Desa Jatibaru Kecamatan Cikarang Timur. Berdasarkan informasi yang diperoleh dari Guru dan siswa SMP Negeri 3 Cikarang Timur sekolahan sering terjadi banjir ketika hujan deras. Ketinggian air banjir di sekolah tersebut bervariasi mulai dari 10 sentimeter hingga 30 sentimeter. 


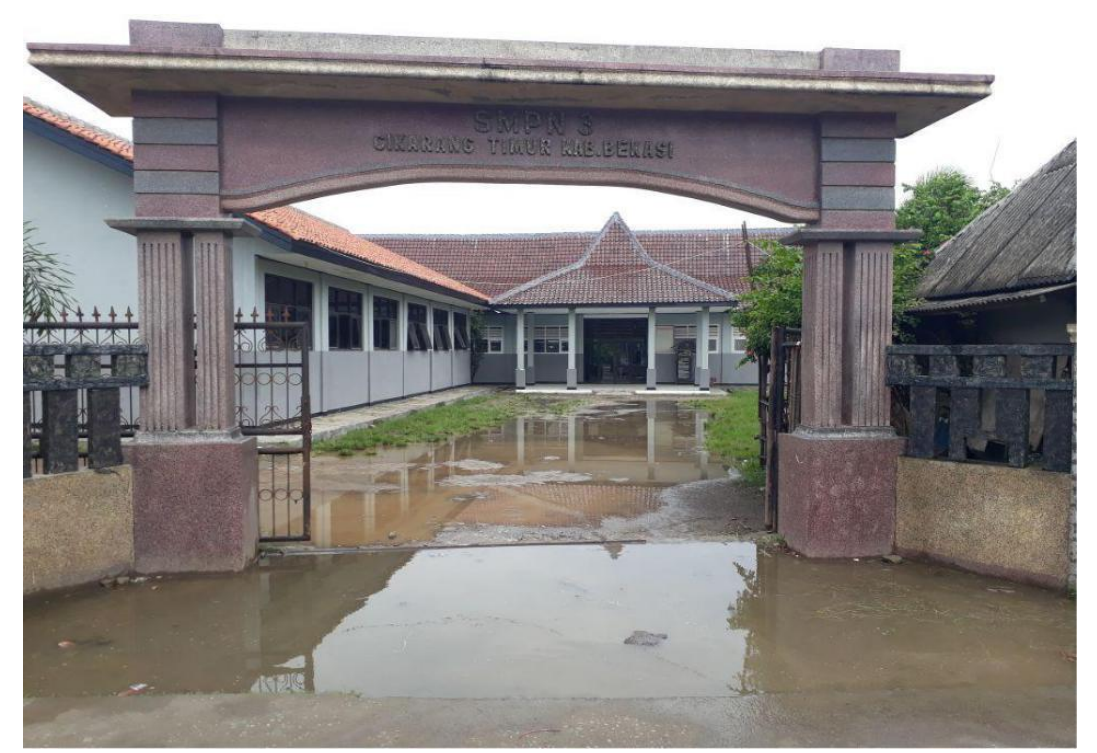

Gambar 2. Kondisi Pintu Masuk SMP Negeri 3 Cikarang Timur

Kondisi geografis dan kontur tanah yang lebih rendah dibanding daerah sekitarnya sehingga mengakibatkan sekolahan tersebut sering menjadi banjir. Selain itu akibat kurangnya resapan karena banyaknya pengecoran jalan dan pembangunan perumahan.

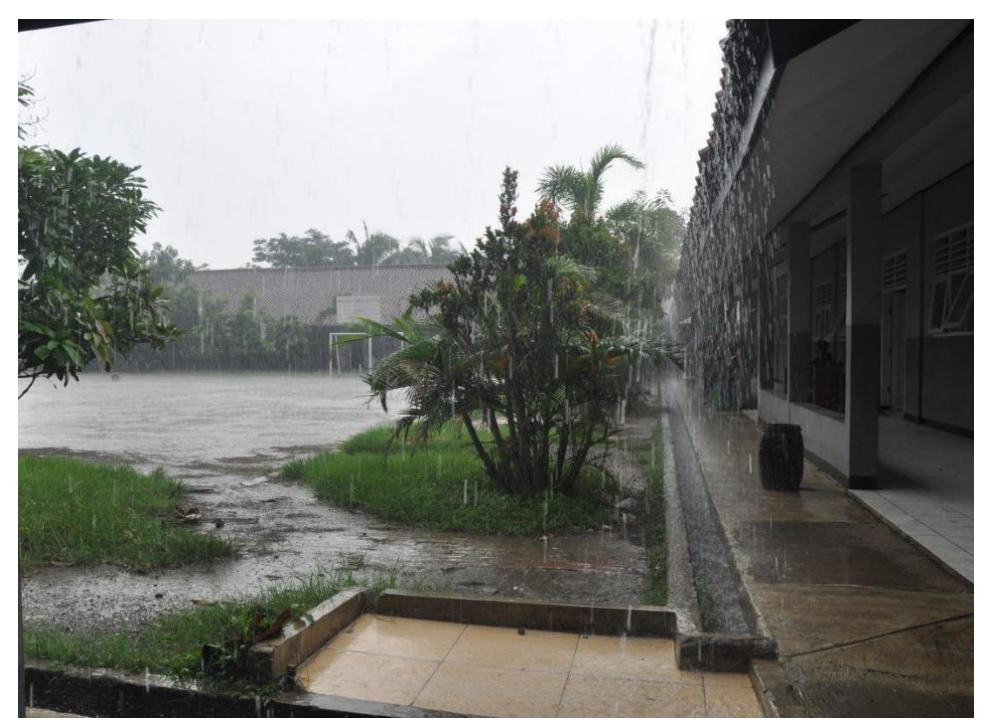

Gambar 3. Kondisi Lapangan SMP Negeri 3 Cikarang Timur

Karena kondisi seperti yang tampak pada gambar 2.1 diatas, maka perlu dilakukan suatu langkah bijak dengan membuat peresapan di SMP Negeri 3 Cikarang Timur melalui kegiatan pengabdian masyarakat di SMP Negeri 3 Cikarang Timur yaitu sosialisasi diharapkan dapat mencegah atau meminimalisir banjir pada saat musim penghujan.

\section{DASAR TEORI}

Lubang Resapan Biopori merupakan metode pembuatan lubang resapan dengan diameterluabang antara 10 hingga $30 \mathrm{~cm}$ dan dengan panjang 30 sampai $100 \mathrm{~cm}$ yang menggunakan media peneutup sampak organik. (Yohana, Griandini, and Muzambeq 2017) Berdasarkan penelitian yang dilakukan dosen pertanian IPB, Kamir R Brata (2006) lubang resapan biopori dapat mencegah terjadinya banjir dengan cara memanfaatkan sampah organir. Fungsi sampah organik pada bagian penutup lubang sebagai penangkap air yang mengalir di sekitar lubang.Air tersebut akan digunakan selain mempermudah proses pmebusukan sampah, juga dapat menjadi cadangan air tanah nantinya. Pembuatan Lubang Resapan Biopori merupakan penerapan teknologi ramah lingkungan yang ramah dan murah. Modal utama dalam proses pembuatan 
Lubang Resapan Biopori adalah adanya kemauan dan kesadaran manusia yang tinggi sebagai upaya dalam mengatasi permasalahan lingkungan hidup yang berkaitan dengan pencemaran air dan lingkungan yang disebabkan oleh sampah. Lubang Respan Biopori merupakan tekologi sederhana yang dapat dimanfaatkan oleh semua masyarakat, karena dalam proses penggunaannya hanya memanfaatkan air hujan.

\section{METODE PELAKSANAAN}

Pada program pengabdian kepada masyarakat kali ini metode pelaksanaan yang digunakan oleh pengusul meliputi sosialisasi dan pendampingan kepada siswa sebagai generasi penerus bangsa tentang bagaimana pentingnya untuk melakukan upaya meminimalisir potensi banjir serta meningkatkan kualitas air tanah dengan adanya penerapan lubang resapan biopori pada sekolah dan diarea sekitar rumah siswa yang sering tergenang air pada saat musim pengujan.

Adapun tahapan pelaksanaan program yaitu sebagai perikut :

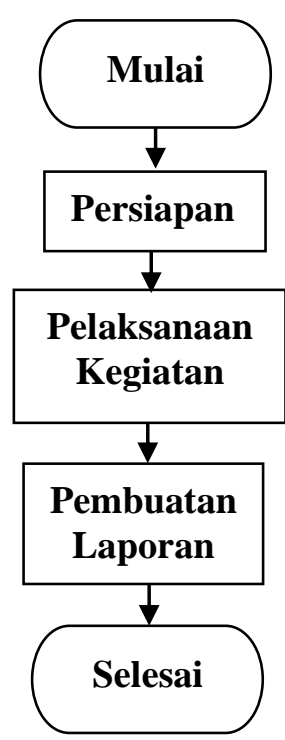

Gambar 4. Diagram Alur Tahap Pelaksanaan Program PKM-M

\section{Persiapan}

Pada tahap persiapan, kegiatan-kegiatan yang dilakukan meliputi :

- Pembentukan tim.

- Pemilihan konsep kegiatan.

- Pemilihan dan peninjauan lokasi yang akan dilaksanakannya kegiatan.

- Persiapan alat dan bahan pelaksanaan kegiatan.

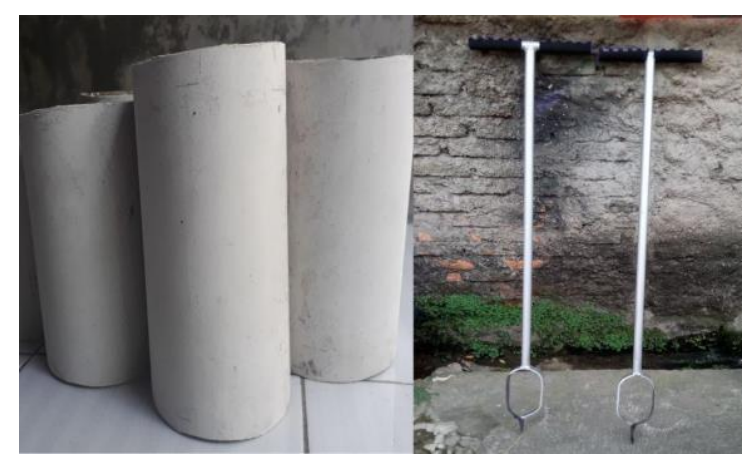

Gambar 5. Persiapan Alat Dan Bahan Pembuatan LRB

\section{Pelaksanaan Kegiatan}

Kegiatan ini akan dilaksanakan setelah tahap pemilihan dan peninjauan lokasi serta tahap persiapan alat dan bahan telah selesai. Kegiatan pengabdian ini akan dilaksanakan di sekolah serta lingkungan rumah siswasiswi SMP Negeri 3 Cikarang Timur yang merupakan daerah yang sering terkena banjir serta peresapan air yang cenderung lambat. Dalam pelaksanaannya siswa-siswi yang mengikuti kegiatan ekstra kurikuler Pramuka menjadi target utama dalam kegiatan ini. 
Pelaksanaan kegiatan ini dibagi menjadi 2 pertemuan, pertemuan pertama untuk melakukan proses sosialisasi dan praktek sedangkan pertemuan kedua untuk melakukan evaluasi atas target yang telah pengusul tetapkan.Adapun pembuatan biopori dilakukan dari skala kecil ke skala besar.

- Skala Kecil

Pembuatan lubang resapan biopori oleh siswa-siswi SMP Negeri 3 Cikarang Timur dan didampingi tim pengabdian masyarakat dari Institut STIAMI di halaman atau lingkungan sekolah pada titik lokasi yang sering tergenang air pada saat musim penghujan (banjir).

- Skala besar

Pembuatan lubang resapan biopori di lingkungan masyarakat seperti di halaman rumah siswa-siswi atau di tempat umum seperti lapangan yang berpotensi terjadinya banjir pada saat musim penghujan.

\section{E. HASIL DAN LUARAN YANG DICAPAI}

\section{Jadwal Kegiatan}

Program pengabdian kepada masyarakat ini dilangsungkan pada periode minggu pertama Desember 2017 hingga minggu kedua Januari 2018.

Tabel 1. Jadwal Kegiatan

\begin{tabular}{|c|c|c|c|c|c|c|c|}
\hline \multirow[t]{2}{*}{ Rincian Kegiat } & \multirow[t]{2}{*}{ Plan/Actual } & \multicolumn{4}{|c|}{ Des 17} & \multicolumn{2}{|c|}{ Jan 18} \\
\hline & & 1 & 2 & 3 & 4 & 1 & 2 \\
\hline \multirow[t]{2}{*}{ Pebentukan Ti } & $\mathrm{P}$ & & & & & & \\
\hline & A & & & & & & \\
\hline \multirow{2}{*}{$\begin{array}{r}\text { Menentukan } \\
\text { Tema dan Jud }\end{array}$} & $\mathrm{P}$ & & & & & & \\
\hline & A & & & & & & \\
\hline \multirow[t]{2}{*}{ Pemilihan Lok } & $\mathrm{P}$ & & & & & & \\
\hline & A & & & & & & \\
\hline \multirow{2}{*}{$\begin{array}{c}\text { Pengurusan } \mathrm{Su} \\
\text { Izin }\end{array}$} & $P$ & & & & & & \\
\hline & A & & & & & & \\
\hline \multirow{2}{*}{$\begin{array}{r}\text { Persiapan Ald } \\
\text { dan Bahan }\end{array}$} & $\mathrm{P}$ & & & & & & \\
\hline & A & & & & & & \\
\hline \multirow{2}{*}{$\begin{array}{c}\text { Pelaksanaan } \\
\text { Kegiatan }\end{array}$} & $\mathrm{P}$ & & & & & & \\
\hline & A & & & & & & \\
\hline \multirow{2}{*}{$\begin{array}{c}\text { Pelaksanaan } \\
\text { Kegiatan( } \\
\text { Evaluasi) }\end{array}$} & $\mathrm{P}$ & & & & & & \\
\hline & A & & & & & & \\
\hline
\end{tabular}

\section{Pembuatan Lubang Resapan Biopori}

Lubang Resapan Biopori(LRB) merupakan salah satu bentuk mitigasi bencana banjir yang mudah diaplikasi di lingkungan tempat tinggal penduduk(Halauddin et al. 2016). Pembuatan Lubang resapan Biopori (LRB) dilakukan secara bertahap di titik-titik yang telah ditetapkan di sekitar sekolah SMP 3 Cikarang Timur. Lubang Resapan Biopori (LBR) yang dibuat terdiri dari 19 LRB, dengan pembagian lokasi pembuat 5 LBR di sekitar wilayah sekolah, dan 14 LRB dibuat di lingkungan perumahan warga yang ada di sekeliling sekolah.

\section{Hasil Yang Dicapai}

\section{Identifikasi Ketercapaian Terhadap Tujuan Program}


Berikut ini adalah identifikasi ketercapaian ditinjau dari luaran progam sosialisasi

1) Dapat mengurangi dan mengatasi masalah banjir yang terjadi di SMP Negeri 3 Cikarang Timur, Kab. Bekasi.

Penempatan posisi pembuatan lubang resapan biopori cukup efektif dalam meminimalisir banjir, air yang menggenang sudah dapat dialihkan kedalam lubang. Jumlah lubang yang masih minim, membuat daya tampung air hujan menjadi belum maksimal.

2) Mengajarkan kepada siswa-siswi dan masyarakat bagaimana cara menjaga lingkungan hidup salah satunya dengan mengajarkan cara pembuatan lubang resapan biopori.

Setelah berlangsungnya kegiatan sosialisasi penerapan lubang resapan biopori, siswa-siswi SMP Negeri 3 Cikarang Timur mengetahui bahwa pentingnya menjaga lingkungan untuk meminimalisir potensi terjadinya bencana, salah satunya bencana banjir yang berdampak pada terhambatnya proses belajar dilingkungan sekolah serta kegiatan dilingkungan tempat tinggal.

\section{Identifikasi Ketercapaian Terhadap Luaran Program}

Berikut ini adalah identifikasi ketercapaian ditinjau dari luaran program pengabdian masyarakat :

1) Produk berupa lubang resapan biopori.

Kegiatan ini menghasilkan produk berupa lubang resapan biopori yang diaplikasikan di lingkungan SMP Negeri 3 Cikarang Timur dan di lingkungan tempat tinggal siswa-siswi yang sering terjadi banjir saat musim penghujan. Selama program ini berlangsung telah terbentuk 5 untuk lingkungan sekolah dan 14 lubang di rumah warga yang dekat dengan lingkungan sekolah.

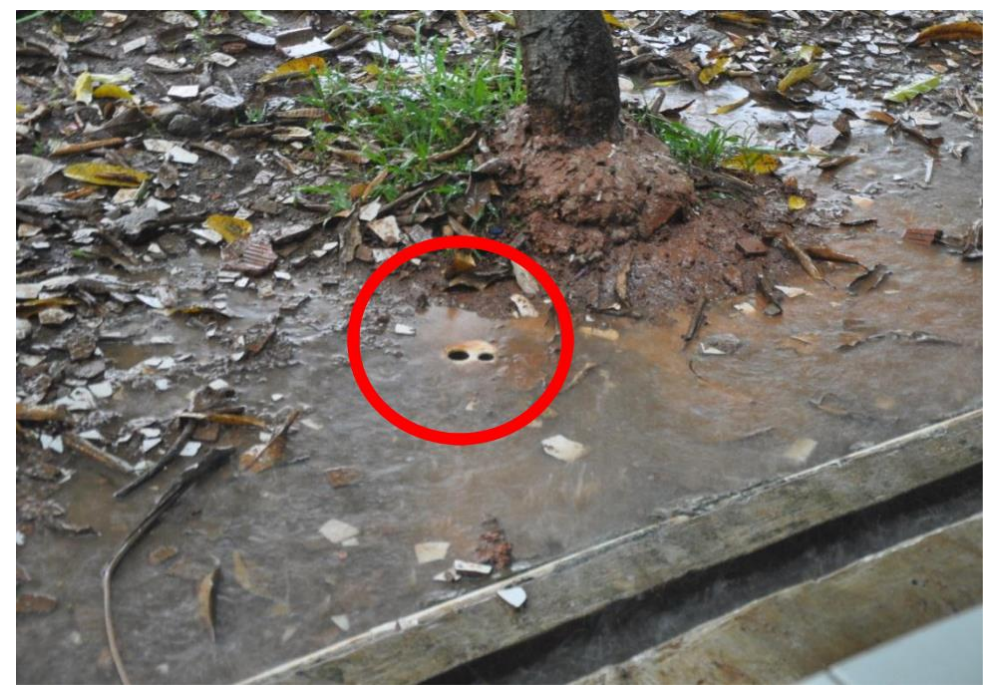

Gambar 8. Kondisi LRB Saat Menampung Genangan Air Hujan

2) Jasa dalam bentuk ilmu pengetahuan untuk siswa-siswi dan masyarakat tentang tata cara pembuatan lubang resapan biopori (LRB).

Sosialisasi mengenai sejarah, manfaat, dan tata cara pembuatan lubang resapan biopori sebagai salah satu solusi untuk meminimalisir potensi banjir di lingkungan sekolah dan tempat tinggal telah disampaikan kepada 40 siswaa-siswi SMP Negeri 3 Cikarang Timur.

3) Metode berupa cara pembuatan lubang resapan biopori.

Demontrasi pembuatan lubang resapan biopori dengan metode bor manual dan pipa bekas sehingga mudah diterapkan oleh siswa-siswi SMP Negeri 3 Cikarang Timur.

\section{Potensi Keberlanjutan}

Keberlanjutan program merupakan aspek penting dalam program pengabdian masyarakat. Pembuatan lubang biopori menjadi salah satu solusi untuk meminimalisir banjir telah mendapatkan dukungan penuh dari pihak sekolah. Hal ini dibuktikan dengan adanya penambahan lubang resapan biopori sebanyak 5 titik di 
lingkungan sekolah. Jumlah tersebut masih akan terus bertambah karena proses pembuatan lubang terus berlanjut.

Keberlanjutan program pengenalan lubang resapan biopori dilingkungan masyarakat juga akan terus berlangsung, dengan banyaknya jumlah siswa-siswi yang telah mengikuti kegiatan ini maka penyebaran informasi tentang cara meminimalisir potensi banjir dengan menggunakan lubang resapan biopori akan semakin populer dimasyarakat.

Keberlanjutan program pengabdian masyarakat tentang Lubang Resapan Biopori juga mendukung beberapa aspek kehidupan, seperti :

1) Aspek Lingkungan

Dengan banyaknya pembuatan lubang resapan biopori, lingkungan akan tetap terjaga, terutama kesuburan tanah dan ketersediaan air tanah.

2) Aspek Ilmu Pengetahuan

Penyampaian informasi tentang teknologi sederhana dalam meminimalisir potensi banjir dengan lubang resapan biopori dapat menambah pengetahuan siswa-siswi serta masyarakat.

\section{F. KESIMPULAN DAN SARAN}

\section{Kesimpulan}

Lubang resapan biopri merupakan suatu metode sederhana dalam upaya untuk meminimalisir potensi terjadinya banjir dengan cara melubangi tanah untuk menambah daya resap tanah atas air hujan. Biopori juga menjadi solusi untuk menjaga kelestarian air tanah terutama menjaga ketersediaan air pada musim kemarau. Selain itu, biopori juga bermanfaat dalam menjaga kesuburan tanah, hal ini dikarenakan adanya ruang aktivitas organisme di dalam tanah. Dengan adanya kegiatan ini, menjadi bukti bahwa pengaplikasian lubang resapan biopori tidaklah sulit karena dapat dilakukan oleh semua kalangan masyarakat seperti yag dilakukan oleh pelajar di SMP Negeri 3 Cikarang Timur.

\section{Saran}

Menjaga kelestarian lingkungan adalah kewajiban seluruh masyarakat. Dengan kreativitas dan perkembangan ilmu pengetahuan diharapkan akan semakin banyak metode dalam upaya untuk melestarikan lingkungan serta pencegahan terjadinya bencana. Dalam proses mempopulerkan biopori sebagai suatu solusi dalam meminimalisir potensi banjir dan menjaga kelestarian lingkungan membutuhkan keterlibatan banyak pihak mulai pemerintah hingga pelajar dan mahasiswa.

\section{G. DAFTAR PUSTAKA}

[1]. BPS. 2017. "Bekasi Regency In Figures.” 32160.1555: 258. https://bekasikab.bps.go.id.

[2]. Halauddin, Suhendra, Refrizon, and Fahri Faisal. 2016. "Pemanfaatan Lubang Resapan Biopori ( LRB ) Dan Perhitungan Permeabilitas Untuk Setiap Titik Lubang Resapan Di Rawa Makmur Permai Bengkulu.” Jurnal Gradien 12(1): 1149-52.

[3]. Tim Biopori Institut Pertanian Bogor.(2007)."Lubang Resapan Biopori (LRB)”.(On-Line). Tersedia:http://www.biopori.com/resapan_biopori.php. (Diakses 29 Desember 2017)

[4]. Yohana, Corry, Dientje Griandini, and Said Muzambeq. 2017. "Penerapan Pembuatan Teknik Lubang Biopori Resapan Sebagai Upaya Pengendalian Banjir." Jurnal Pemberdayaan Masyarakat Madani (JPMM) 1(2): 296-308.

[5]. Prameswari, Diana, Supriyanto, et.all.2015."Aplikasi Lubang resapan Biopori dan Cross Drain untuk Rehabilitasi di Jalan Sarad". Jurnal Penelitian Hutan dan Konservasi Alam(JPHKA) 12(2): 177-189.

[6]. Hafizh, Muhammad, Terunajaya.2014. Kajian Efektivitas Lubang Resapan Biopoi dalam Merduksi Debit Banjir Akibat Air Limpasan Hujan (Run-Off Pada Kawasan Perumahan ( Studi Kasus: Perumahan Classic 3,Medan). Jurnal Teknik Sipil USU 3(2). 